\title{
MEWUJUDKAN TATA KELOLA PEMERINTAHAN YANG BAIK DI BIDANG PERTANAHAN MELALUI PENDAFTARAN TANAH SISTEMATIS LENGKAP
}

\author{
Achieving Good Governance In The Land Sector Throngh A Complete Systematic Registration \\ of Land
}

\author{
Hadi Arnowo \\ Pusat Pengembangan Sumber Daya Manusia Kementerian Agraria dan Tata Ruang/ Badan \\ Pertanahan Nasional \\ Jl. Akses Tol Cimanggis, Wanaherang, Bogor \\ E-mail : h_amowo@yahoo.com
}

Naskal diterinna tanggal 4 Noventber 2019. Naskah direvisi tanggal 10 November 2019. Naskah disetwjui tanggal 18 November 2019

\begin{abstract}
Abstrak
Sektor pertanahan sangat strategis dan vital dalam kegiatan pembangunan sehingga diperhukan tata kełola pesnerintahan yang baik untuk setiap kegiatan layanan pertanahan. Salah satu kegiatan layanan pertantahan yang utama adalah Pendaftaran Tanah Sistematis Lengkap (PTSL). Penelitian mengenai penerapan fata ketola pemerintahan dalam kegiatan PTSL bertujitan untuk mengefahni bentuk implementasi tata pemerintahan yang baik di dalam keglatan PTSL. Masatah yang diangkat adalah mengenai penerapan asas pemerintahan yang baik di dalam tahapan kegiatan PTSL. Metode penelitian yang dilakukan adalah deskripst anafitik dengan pengambitan data melatui observasi dan wawancara. Iokasi penetitian dilakukan di Kantor Pertanahan Kabupaten Kepahiang, Provinsi Bengkuht. Perkembangan kehidupan masyarakat di Indonesia menunjukkan semakin tingginya harapan untuk memperoleh petayanan yang baik di bidang pertanaham. Hal tersebut hans ditindaklawjuti dengan penerapan prinsip-pritsip pemerintahan yang baik yaitu kepastian hikum dan keterbukaan. Pelaksanaan PTSL oleh Kantor Pertanahan Kabupaten Kepahtang sesual dengan ketentuan yang bertaku. Kegiatan pengumputan dan penellitan data fistk dan yurldis dilakukan secara akurat dan komprehensif sebagai bentuk penerapan prinsip kepastian hukum. Setelah terbitnya keputusan pembertan hak atas tanah, penerbitam dan penyerahan sertiptkat dilakukan secara transparan dan diterina oleh pemilik tanah yang merupakan penerapan prinsip keterbukaan. Tata kelola penerintahan teloh dilakukan dengan baik oleh Kantor Pertanahan Kabuputen Kepahiang dalan melaksanakan kegiatan PTSL sehingga realisasi kegiatan sesuai dengan target jumlah dan waktu.
\end{abstract}

Kafa Kunci: Tata Keloła Penerintahan, Kepastian Hukum, Keterbukaan

\begin{abstract}
The kand sector is very strategic and vital in development activities so good governance is needed for each land service activity. One of the main land service activities is Complete Systematic Land Registration (PTSL). Research on the application of governance in PTSL activities aims to find out the forms of implententing good governance in PTSL activities. The problem raised was regarding the application of the principte of good governance in the stages of PTSL activities. The reseanch method used is analytic description by taking data through observation and interviews whilst the location of the study was condheted at the Kepahiang District Land Office, Bengkulu Province. The development of commumity life in Indonesia shows the high hopes for obtaining good services in the land sector. This must be followed up with the application of good governance principles, namely legal certainty and openness. PTSL inplementation by the Kepahiang District Land Office in accordance with applicable regulations. Physical and juridical data collection and research activities are cartied out accurately and conprehensively as a form of applying the principte of legal certainty. After the issuance of the decision to grant land rights, the issuance and surrender of certificates is carried out transparently and accepfed by the tand owner which is the application of the principle of openness. Good governance has been carried out by the Kepahiang District Land Office in inplententing PTSL activities so that the reatization of activitles is in accordance with the target number and time.
\end{abstract}

Keywords: Governance, Legal certainty, Openness 


\section{PENDAHULUAN}

\section{Latar Belakang}

Pasal 19 Undang-Undang Nomor 5 Tahun 1960 tentang Peraturan Dasar Pokok-Pokok Agraria atau dikenal Undang-Undang Pokok Agraria berisi "Untuk menjamin kepastian hukum oleh Pemerintah diadakan pendaftaran tanah diselurth wilayah Republik Indonesia menurut ketentuan-ketentuan yang diatur dengan Peraturan Pemerintah". Berdasarkan pasal tersebut maka pendaftaran tanah lekat dengan tugas pemerintah untuk memberikan kepastian hukum bagi masyarakat.

Indonesia memiliki wilayah teritorial yang luas dengan jumlah bidang tanah sebanyak 126 juta. Dari jumlah tersebut, jumlah tanah terdaftar sebanyak 47 juta bidang tarah dan 79 juta bidang tanah belum terdaftar. Pemerintah mengeluarkan kebijakan percepatan pendaftaran tanah dengan target pada akhir tahun 2024 seluruh bidang tanah di Indonesia terdaftar.

Untuk percepatan pendaftaran tanah tersebut di adas, maka langkah yang dilakukan adalah dengan Pendaftaran Tanah Sistematis Lengkap (PTSL). Kegiafan PTSL adalah kegiatan pendaftaran tanah pertama kali yang dilakukan dalam satu wilayah desa/ kelurahan.. Pelaksanaan kegiatan PTSL dimulai pada tahun 2017 dengan target dan realisasi sebanyak 5 juta bidang tanah dan tahun 2018 sebanyak 7 juta bidang tanah. Target PTSL pada tahun 2019 sebanyak 9 juta bidang tanah.

Tuntutan masyarakat terhadap pemerintah pada era reformasi adalah terwujudnya pemerintahan yang bersih. Hal tersebut sejalan dengan Ketetapan Majelis Permusyawaratan Rakyat Republik Indonesia Nomor XI/MPR/1998 Tentang Penyelenggara Negara Yang Bersih dan Bebas Korupsi, Kolusi dan Nepotisme. Birokrasi bebas dari KKN (Korupsi, Kolusi dan Nepotisme) merupakan bagian dari tata kelola pemerintahan yang baik (good governance). Dalam hal ini unsur trias politica yaitu yudikatif, eksekutif dan legislatif turut bertanggungjawab unfuk terwujudnya tata kelola pemerintahan yang baik. Dalam konteks pemberantasan korupsi, good governance sering diartikan sebagai penyelenggaraan negara yang bersih dari praktek korupsi (Komite Nasional Kebijakan Governance, 2008)

Kegiatan PTSL yang telah berjalan sejak tahun 2017 dilaksakan oleh seluruh kantor pertanahan kabupaten/kota. Seluruh tahapan pekerjaan PTSL telah dilaksanakan dengan ketentuan yang berlaku. Bekerja sesuai dengan ketentuan yang berlaku belum cukup karena harus dilakukan dengan prinsip-prinsip good governance. Hasil kegiatan PTSL yang diharapkan adalah mencapai target pekerjaan dengan pelaksanaannya sestuai ketentuan yang berlaku serta penerapan prinsip-prinsip tata kelola pemerintahan.

Penelitian secara khusus mengenai kegiatan PTSL dan tata pemerintahan yang baik belum tersedia. Meskipun demikian terdapat hasil penelitian mengenai PTSL yaitu Kurwiawan et al. (2018) yang menunjukkan terdapat hubungan yang signifikan antara faktor sosial dan faktor ekonomi dengan ekspektasi terhadap PTSL. Hal tersebut menunjukkan bahwa pemberian sertipikat tanah memilik PTSL sebagai salah satu bentuk keinginan pemerintah untuk mewujudkan tanah-tanah yang terdaftar di seluruk wilayah Indonesia.

Penelitian mengenai good gavencance dihasilkan oleh Heriyanto (2015) yang menyebutkan prinsip-prinsip good governance adalah transparansi, partisipasi, akuntabilitas, penegakan hukum, daya tanggap, profesionalitas, efektivitas dan efisiensi, orientasi konsensus. Putra (2017) mempunyai pendapat yang hampir sama dengan tambahan visi strategis.

\section{Rumusan Masalah}

Masalah yang diidentifikasi sebagai bahasan utama dalam penulisan jurnal ini adalah sebagai berikut.

1. Bagaimanakah praktik tata ketola pemerintahan pada setiap tahapan pekerjaan Pendaftaran Tanah Sistematis Lengkap?

2. Faktor-Faktor apa saja yang dapat mewujudkan tata kelola pemerintahan yang 
baik pada Pendaftaran Tanah Sistematis Lengkap?

\section{Tujuan Penulisan}

Tujuan karya tulis ini adalah untuk mengetalui bentuk implementasi tata pemerintahan yang baik melalui kegiatan Pendaftaran Tanah Sistematis Lengkap (PTSL). Manfaat karya tulis ini adalah sebagai bahan masukan bagi instansi pemerintah baik di tingkat pusat maupun daerah saling bersinergi melalui program Pendaftaran Tanah Sistematis Lengkap untuk mewujudkan kemakmuran rakyat.

\section{TINJAUAN PUSTAKA}

Pengertian governance memurut UNESCAP adalah "the process of decisionmaking and the process by which decisions are implemented (or not implemented)". Pengertian governance menurut pendapat Gambhir Blatta dalam Nugroho (2009, hal. 16) yaitu hubungan antara pemerintah dan warga negara yang memungkinkan kebijakan dan program publik untuk dirunuskan, diimplementasikan, dan dihitung.

Istilah governance dan government dapat digunakan unfuk menggambarkan proses pemerintahan. Walaupun demikian terdapat perbedaan yaitu government merujuk pada pelaku (pemerintah), sedangkan govennance merujuk pada prosesnya (pemerintahan). Dalam hal ini, governance diartikan sebagai 'the act of government' (Pratikno, 2005).

Selanjutnya Dwiyanto (2014) memperhuas pengertian governance tidak semata-mata terbatas pada pemerintah tetapi juga institusiinstitusi lain seperti LSM, perusahaan swasta hingga warganegara untuk melakukan proses memerintah (governing) secara bersama-sama. Pendapat tersebut juga diutarakan oleh Widodo (2018) yaitu terjadi perubahan paradigma yaitu dari rule government menjadi good govennance. Pemerintah tidak lagi hanya menyandarkan pada peraturan dan pemerintah atau negara (state) tetapi juga melibatkan unsur di luar pemerintah yaitu sektor swasta (private sector) dan masyarakat sipil (civil society).
UNESCAP menyebutkan ciri-ciri governance adalah partictpatory, consensus oriented, accountable, transparent, responsive, effective and efficient, equitable and inclusive and nule of low. Dapat diartikan bahwa apabila seluruh ciri-ciri governance tersebut dilakukan maka akan terwujud good governance. Mengenai prinsip good governance menurut UNDP di dalam Dwiyanto (2014) adalah partisipasi, transparansi, akuntabel, efektif dan efisien, kepastim hukum, responsif, konsensus seria setara dan inklusif.

Ridwan (2013) mengangkat istilah algemene beginselen van behoorlijk bestuur yang diartikan sebagai asas-asas umum pemerintahan yang baik. Menurut Koentjoro Purbopranoto dan SF. Marbun di dalam Ridwan (2013) asas-asas umum pemerintahan yang baik meliputi diantaranya kepastian hukum (principle of legal security), asas bertindak cermat (principle of carefulness), asas kesamaan dalam mengambil keputusan (principle of equality) dan asas transparansi dalam pelayanan publik (principle of transparency in public service).

Laporan Bank Dunia pada tahun 1989 menyebutkan bahwa pelaku governance meliputi pemerintah, bisnis dan civil society yang lrarus bersinergi membangun konsensus, sehingga peran negara tidak lagi bersifat regulatif, tetapi hanya sebatas fasilitatif. Karakteristik good governance di dalam laporan tersebut adalah masyarakat sipil yang kuat dan partisipatoris; terbuka; pembuatan kebijakan yang dapat diprediksi; eksekutif yang bertanggungiawab dan birokrasi yang profesional (Prianto, 2011).

Asas-asas umum pemerintahan yang baik secara umum diterjemahkan sebagai layanan publik yang baik. Indikator pelayanan publik yang baik menurut Lenvine (1990) di dalam Subarsono (2014) terdiri dari responsivitas terhadap keinginan dan tuntutan pengguna layanan, responsibilitas pemberian pelayanan berdasarkan ketentuan administrasi dan akumabilitas sesuai norma-norma yang berkembang di masyarakat. 
Nugroho (2016, hal. 17) menambahkan bahwa good governance berkaitan dengan excellence public policy yang meliputi transparansi, akuntabilitas dan fairness. Secara umum governance memiliki makna tata kelola penerintahan.

Tantangan untuk mewujudkan tata pemerintahan yang baik terletak pada upaya mewujudkan tiga karakteristik yaitu praktik good governance harus membagi ruang kepada semua pihak untuk berpartisipasi dan bersinergi dengan pemerintah; kedua dalam praktik good governance pemerimtah harus bertindak lebih efektif untuk mewujudkan kesejahteraan bersama dan ketiga adalah terwujudnya pemerintah yang bersih dan bebas dari praktik Korupsi, Kolusi dan Korupsi (KKN) (Dwiyanto, 2014)

Untuk menganalisis bagaimana tata kelola pemerintahan dilaksanakan adalah dengan menggunakan elemen sistem kebijakan di bawah ini:

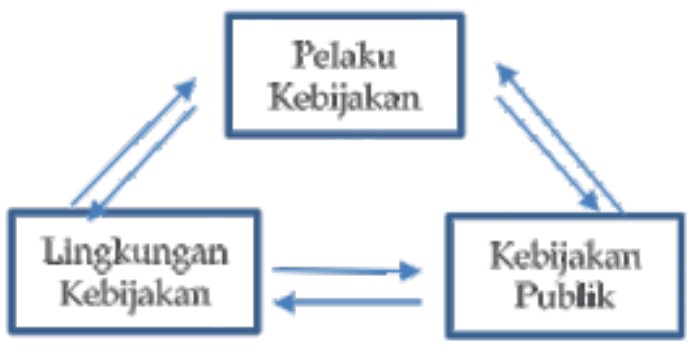

Sumber: Thomas R. Dye dalam Dumn,2000, hal. 110

Gambar 1

Sistem Kebijakan Publik

Di dalam konteks penyelenggaraan Pendaftaran Sistematis Lengkap (PTSL), maka elemen-elemen di dalam sistem kebijakan adalah sebagai berikut:

1. Kebijakan publik adalah program PTSL yang dilaksanakan oleh Kementerian ATR/BPN di seluruh wilayah Indonesia

2. Lingkugan kebjjakan adalah wilayahwilayah dimana lokasi kegiatan PTSL

3. Pelaku kebijakan: adalah pelaksana kegiatan PTSL oleh setiap petugas dan pejabat di lapangan maupun di kantor

\section{METODE PENELITIAN}

Penelitian pada tulisan ini menggunakan metode kualitatif yang bersifat deskriptif analitik. Pengertian penelitian deskriptif adalah upaya menjelaskan secara rinci, sistematis dan menyeluruh segala sesuatu mengenai penyelenggaraan Pendaftaran Tanah Sistematis Lengkap (PTSL) yang dikaitkan dengan tata kelola pemerintahan yang baik. Sedangkan pendekatan analitik yaitu menganalisis keterkaitan teori dengan penjelasan empiris terhadap masalah yang dikemukakan.
Pengumpulan data dilakukan melalui metode observasi (pengamatan) dan wawancara mendalam (in-depth interview). Selanjutnya data yang terkumpul dikelompokkan berdasarkan tahapan kegiatan PTSL. Data yang telah dikelompokkan tersebut kemudian dianalisis yaitu dengan membandingkan antara praktik kegiatan dengan ketentuan pelaksanaan PTSL dan kemudian dijelaskan berdasarkan teori mengenai good governance.

Lokasi penelitian adalah di Kantor Pertanahan Kabupaten Kepahyang, Provinsi Bengkulu. Pelaksanaan kegiatan PTSL yang diteliti adalah pada tahun anggaran 2019 dengan target sebanyak 1350 bidang dan realisasi sebanyak 1360 bidang yang diselesaikan pada bulan Juli 2019.

\section{PEMBAHASAN}

Praktik Tata Kelola Pemerintahan Pada Pendaftaran Tanah Sistematis Lengkap

Tujuan program PTSL dinyatakan di dalam Pasal 2 Ayat 2 Peraturan Menteri ATR/Kepala BPN Nomor 6 Tahun 2018 tentang 
Pendaftaran Tanah Sistematis Lengkap, adalah untuk percepatan pemberian kepastian hukum dan perlindungan hukum Hak atas Tanah masyarakat secara pasti, sederhana, cepat, lancar, aman, adil, merata dan terbuka serta akuntabel. Isi dari tujuan PTSL tersebut menyiratkan penerapan prinsip-prinsip tata kelola pemerintahan. Dalam hal ini tuntutan bagi petugas PTSL untuk melaksanakan ketentuan PTSL di dalam peraturan tersebut akan mewujudkan tata kelola pemerintahan yang baik (good governance)

Keuntungan bagi masyarakat dengan kegiatan PTSL berupa:

1. Kepastian hak atas tanah dengan tanpa biaya untuk kegiatan teknis pertanahan

2. Pemberian sertipikat hak atas tanah sesuai dengan target kegiatan

3. Memperoleh kesempatan akses modal secara kolektif dan mudah karena difasilitasi pemerintal pasca sertipikat

Pelaksanaan kegiatan Pendaftaran Tanah Sistematis Lengkap terikat dengan ketentuan peraturan yang secara garis besar terdiri dari:

1. Perencanaan kegiatan

2. Penyuluhan

3. Pengumpulan data fisik dan pengumpulan data yuridis

4. Penelitian data yuridis untuk pemboktian hak

5. Pengumuman data fisik dan data yuridis serta pengesahannya

6. Penegasan konversi, pengakuan hak dan pemberian hak

7. Pembukuan hak;

8. Penerbitan sertipikat hak atas tanah

Keseluruhan tahapan kegiatan di atas harus dilaksanakan oleh petugas sesuai ketentuan yang berlaku. Batasan-batasan dalam pekerjaan tersebut di atas adalah berdasarkan petunjuk teknis pada masing-masing komponen teknis serta peraturan perundang-undangan di bidang pertanahan.

Kantor Pertanahan Kabupaten Kepahiang memperoleh target PTSL sebanyak 1.360 bidang dengan lokasi kegiatan sebagai berikut:

- Desa Suro Ilir, Kecamatan Ujan Mas

- Desa Suro Bali, Kecamatan Ujan Mas
- Desa Daspeta II, Kecamatan Ujan Mas

- Desa Batu Ampar, Kecamatan Merugi

- Desa Sukamerindu, Kecamatan Kepahiang

- Desa Talang Karet, Kecamatan Tebat Karai

- Desa Mekarsari, Kecamatan Kabawetan

Pada tahapan perencanaan kegiatan prinsip pemerintahan yang terkait adalah prinsip kesamaan dan prinsip transparansi. Lokasi yang ditetapkan untuk Pendaftaran Tanah penetapan lokasi mengacu pada ketentuan pada Pasal 7 Peraturan Menteri ATR/BPN No. 6 Tahun 2018 dan harus meliputi seluruh bidang tanah di desa. Ini berarti seluruh bidang tanah memiliki kesempatan didaftarkan sehingga terhindar terjadinya permainan dalam penentuan peserta.

Lokasi PTSL ditentukan berdasarkan permohonan dari pemerintah desa. Selonjutrya dari permohonan tersebut dipertimbangkan kesiapan masyarakat desa untuk menjadi peserta PTSL. Berdasarkan pertimbangan tersebut Kepala Kantor Pertanahan Kabupaten Kepahiang menetap-kan nama-nama desa terpilih sebagai lokasi PTSL.

Perencanaan kegiatan secara formal berupa persiapan administrasi dan persiapan teknis. Persiapan administrasi berupa pembuatan surat keputusan tentang penetapan lokasi, tim admnistrasi dan pengumpulan data serta ketentuan administrasi lainnya. Sedangkan persiapan teknis berupa persiapan peta kerja dan pengecekan peralatan yang akan digunakan dalam survei pemetaan.

Kegiatan penyuluhan merupakan salah satu bagian tahapan yang penting untuk kelancaran tugas. Pihak yang diundang adalah seluruh masyarakat desa beserta pamong dan kepala desa, pibak kepolisian dan kejaksaan serta unsur terkait dari Pemerintah Kabupaten Kepahiang. Materi penyuluhan terkait dengan kegiatan petugas di lapangan dan dokumendokumen yang harus diserahkan oleh pemilik tanah. Selain itu tidak kalah pentingnya adalah mengenai biaya PTSL yang ditanggung pemerimtah dan yang tidak ditanggung.

Biaya yang ditanggung oleh Kantor Pertanahan Kabupaten Kepahiang adalah biaya operasional baik di lapanan maupun di kantor. Termasuk di dalamnya adalah biaya makan dan 
akomodasi petugas bukan menjadi menjadi tanggung jawab masyarakat. Sedangkan biaya yang harus ditanggung oleh masyarakat berupa biaya yang timbul sebagai akibat dikeluarkannya berbagai surat keterangan dari pihak yang berwenang serta pajak terkait. Pefugas penyuluh juga menyampaikan kepada masyarakat mengenai kewajiban untuk melengkapi syaratsyarat pembuktian hak serta pemasangan batas.

Pihak-pihak yang diundang dalam penyuluham PTSL adalah masyarakat desa termasuk para pemuka desa, aparatur daerah termasuk di dalamnya perangkat desa setempat dan kecamatan serfa Forum Koordinasi Pimpinan Daerah (Forkopimda). Banyak pihak yang diundang untuk menjadi saksi mengenai materi yang disampaikan secara transparan. Selain itu masyarakat dapat mengetahui peran masing-masing aparat yang terkait dengan pengumpulan data fisik dan yuridis.

Materi penyuluhan disampaikan oleh petugas dengan bahasa yang mudah dimengerti dan lengkaps. Dalam hal ini masyarakat diberikan keleluasaan untuk berfanya dan memberikan pendapat. Masyarakat harus menerima informasi secara tuntas (wellinformed) dan tidak ada informasi yang disembunyikan.

Tahap pelaksanaan kegiatan sangat penting karena terdiri dari pengumpulan dan pengolahan data serta pengumuman. Pengumpulan data fisik identik dengan kegiatan pengukuran dan pemetaan. Bidang tanah yang diukur dengan batas-batas tanah yang telah ditetapkan oleh pemilik tanah dan tetangga berbatasan tanpa campur tangan petugas menunjukkan adanya transparansi dalam pelayanan pengukuran dan pemetaan. Pengumpulan data fisik dan data yuridis berdasarkan jadwal petugas turun lapang. Hal ini membuktikan diterapkannya prinsip kesamaan karena semua bidang tanah akan diukur.

Prinsip lainnya adalah prinsip kepastian hukum dalam pengumpulan dan pengolahan data serta pengumuman. Prinsip ini terkait erat dengan sikap profesionalisme dan moral yang ditunjukkan oleh petugas. Sikap profesionalisme mengandtong makna tidak menganggap remeh dan pekerjaan serta bertanggung jawab baik secara teknis maupun moral pada hasil pekerjaan. Apabila petugas metaksanakan prinsip ini maka pelaksnaan kebijakan publik pada takap ini telah berjalan dengan baik.

Penelitian data yuridis umtuk pembuktian hak dilakukan dengan data dan fakta sebenarnya. Pengumuman data fisik dan data yuridis serta pengesahannya hasil dari pembuktian hak. Akhir dari tahapan pelaksanaan kegiatan adalah penetapan hak melalui proses pengakuan atau penegasan hak dan pemberian hak. Seluruh kegiatan di dalam tahapan pelaksanaan harus dilakukan menggunakan prinsip kepastian bukum.

Prosedur pengambilan daia oleh petugas PTSL dari Kantah Kab. Kepahiang sesuai dengan petunjuk teknis dari masing-masing bidang. Pengambilan data fisik telah dilakuikan sesuai dengan petunjuk teknis yang diterbitkan oleh Dirjen Infrasiruktur Keagrariaan dan data yuridis berdasarkan petunjuk teknis dari Dirjen Hubungan Hukum Keagrariaan. Sehuruh data fisik dan yuridis kemudian diolah dan dihasilkan data mengenai subjek dan objek penguasaan tanah.

Sebelum pengukuran bidang tanah pemilik tanah harus memasang tanda batas disaksikan oleh telangga berbatasan. Pada proses ini petugas mengukur dan memetakan bidang tanah sesuai penunjukan batas dan kesaksian tetangga berbatasan. Tahapan ini sangat penting dilakukan agar tidak terjadi sengketa batas bidang tanah. Petugas yuridis melakukan pengumpulan dokumen pendukung dam keterangan mengenai penguasaan tanah. Petugas kemudian meneliti dokumen yang terkumpul mengenai riwayat kepemilikan tanah. Data fisik dengan data yoridis hacus sinkron dan sesuai dengan fakta di lapang.

Selama bekerja petugas tidak memungut dalam bentuk apapun dari masyarakat terkait pekerjaan. Dengan sikap integritas yang ditunjukkan petugas maka masalah korupsi dalam bentuk pungutan liar dapat ditiadakan. Dengan kondisi medan apapun petugas juga dituntut bekerja secara profesional sehingga data yang dihasilkan akurat. 
Data mengenai subjek dan objek hak hasil dari penelitian dan pengolahan data pada takap berikutnya adalah diumumkan di tempat berbeda yaitu di Kantor Pertanahan, di kantor desa/kelurahan dan di lokasi PTSL. Tujuan dari pengumuman tersebut adalah untuk memberikan akses seluas-luasnya kepada masyarakat. Apabila terdapat gugatan terhadap hasil pengumpulan data maka dapat diselesaikan secara administrasi dan hukum.

Penetapan hak di dalam kegiatan PTSL dapat ditempuh melalui mekanisme pengakuan atau penegasan hak dan pemberian hak. Masingmasing mekanisme tersebut sesuai dengan riwayat tanah. Di dalam penentuan mekanisme penetapan hak tersebut petugas harus cermat sehingga administrasi penetapan hak telah sesuai dengan aturan. Ketidakcermatan petugas dalam menentukan penetapan hak dapat berakibat pada potensi gugatan Tata Usaha Negara (TUN) apabila terdapat masalah sengketa perkara pertanahan.

Tahap penyerahan kegiatan berupa pembukuan hak dan penerbitan sertipikat hak atas tanah. Pembukuan hak untuk tanah-tanah yang telah ditetapkan haknya melalui PTSL berarti telah ditetapkan menjadi tanah-tanah yang terdaftar. Tanah-tanah yang telah terdaftar atau dibukukan hak atas tanahnya maka dapat diterbitkan sertipikat. Prinsip-prinsip pemerintahan yang diterapkan pada tahapan ini adalah prinsip kesamaan, transparansi dan bukum.

Masyarakat pemilik tanah di dalam lokasi PTSL mempunyai kesempatan untuk mendapatkan kepastian hukum hak atas tanahnya dengan mudah dan murah. Berdasarkan penjelasan mengenai keterkaitan tahapan kegiatan PTSL dengan prinsip-prinsip pemerintahan yang baik, maka kegiatan PTSL dapat menjadi model penerapan pemerintahan yang baik di bidang pertanahan.

Pembuktan hak merupakan tindak lanjut dari penetapan hak dimana bidang tanah yang telah memperoleh status tanah didaftarkan untuk diterbitkan sertipikat. Mengingat sertipikat merupakan produk hukum yang terus digunakan untuk berbagai keperluan, maka data yang tercetak harus sesuai dengan data yang sebenamya. Kemungkinan salah entri atau salah gambar dapat terjadi sehingga petugas mengecek kembali sebelum mencetak sertipikat.

Penyerahan sertipikat merupakan bagian akhir dari pekerjaan PTSL. Meskipun relatif paling mudah dibanding dengan kegiatan laimnya, petugas tetap bekerja secara profesional. Sesuai dengan ketentuan, pemilik tanah harus menerima sertipikat tanah. Apabila tidak dapat mengambil maka dapat dikuasakan kepada pihak ketiga dengan prosedur dan ketentuan yang berlaku.

Data pada Tabel 1 menunjukkan kebijakan publik yang diambil pada setiap kegiaian PTSL. Kebijakan publik yang dikerjakan dengan baik merupakan perwujudan tata kelola pemerintahan pada masing-masing kegiatan. Sebaliknya apabila kegiatan tidak dikerjakan dengan baik, maka hal tersebut berpotensi terjadinya penyalahgunaan kewenangan dan selanjutnya akan berkonseknensi hukum.

\section{Tabel 1}

Kegiatan PTSL Dalam Sistem Kebijakan

Publik

\begin{tabular}{|c|l|l|}
\hline Kegiatan & $\begin{array}{l}\text { Kebijakan } \\
\text { Publik }\end{array}$ & $\begin{array}{l}\text { Potensi } \\
\text { Penyalahgu- } \\
\text { naan }\end{array}$ \\
\hline $\begin{array}{c}\text { Perencanaan } \\
\text { kegiatan }\end{array}$ & $\begin{array}{l}\text { Penentuan } \\
\text { lokasi secara } \\
\text { jelas } \\
\text { berdasarkan } \\
\text { usulan dari } \\
\text { pemerintah } \\
\text { desa dan } \\
\text { tidak ada } \\
\text { diskriminasi }\end{array}$ & $\begin{array}{l}\text { Penentuan } \\
\text { lokasi } \\
\text { berdasarkan } \\
\text { usulan dari } \\
\text { pihak tertentu }\end{array}$ \\
\hline $\begin{array}{c}\text { Penyuluhan } \\
\text { Transparansi } \\
\text { biaya dan } \\
\text { prosedur }\end{array}$ & $\begin{array}{l}\text { Materi } \\
\text { penyuluhan } \\
\text { multi tafsir } \\
\text { terkait biaya }\end{array}$ \\
\hline $\begin{array}{c}\text { Pengumpulan } \\
\text { data }\end{array}$ & $\begin{array}{l}\text { Kegiatan dan } \\
\text { lapang harus } \\
\text { tuntas dan } \\
\text { profesional }\end{array}$ & $\begin{array}{l}\text { Pungli } \\
\text { pekerjaan } \\
\text { tidak } \\
\text { profesional }\end{array}$ \\
\hline $\begin{array}{c}\text { Penelitian } \\
\text { data }\end{array}$ & $\begin{array}{l}\text { Pemeriksaan } \\
\text { data harus } \\
\text { teliti dan } \\
\text { tuntas }\end{array}$ & $\begin{array}{l}\text { Pekerjaan } \\
\text { tidak } \\
\text { profesional }\end{array}$ \\
\hline
\end{tabular}




\begin{tabular}{|c|l|l|}
\hline $\begin{array}{c}\text { Pengumuman } \\
\text { data }\end{array}$ & $\begin{array}{l}\text { Akses } \\
\text { informasi } \\
\text { yang luas }\end{array}$ & $\begin{array}{l}\text { Penyembunyi } \\
\text { an informasi } \\
\text { dengan } \\
\text { memanfartkan } \\
\text { keterbatasan } \\
\text { pengumuman }\end{array}$ \\
\hline Penetapan hak & $\begin{array}{l}\text { Jaminan } \\
\text { kepastian } \\
\text { hukum }\end{array}$ & $\begin{array}{l}\text { Pekerjaan } \\
\text { tidak } \\
\text { profesional }\end{array}$ \\
\hline $\begin{array}{c}\text { Pembukuan } \\
\text { lak }\end{array}$ & $\begin{array}{l}\text { Pendaftaran } \\
\text { hak atas } \\
\text { tanah at }\end{array}$ & $\begin{array}{l}\text { Pekerjaan } \\
\text { tidak } \\
\text { profesional }\end{array}$ \\
\hline $\begin{array}{c}\text { Penyerahan } \\
\text { sertipikat }\end{array}$ & $\begin{array}{l}\text { Penyerahan } \\
\text { sertipikat } \\
\text { kepada } \\
\text { pemilik }\end{array}$ & $\begin{array}{l}\text { Progli dan } \\
\text { pekerjaan } \\
\text { tidak } \\
\text { profesional }\end{array}$ \\
\hline
\end{tabular}

(Sumber: hasil olahan 2019)

Berdasarkan tahapan kegiatan PTSL yang disebutkan di atas, maka bentuk penerapan asasasas umum pemerintahan yang baik terdapat dalam skema berikut ini:

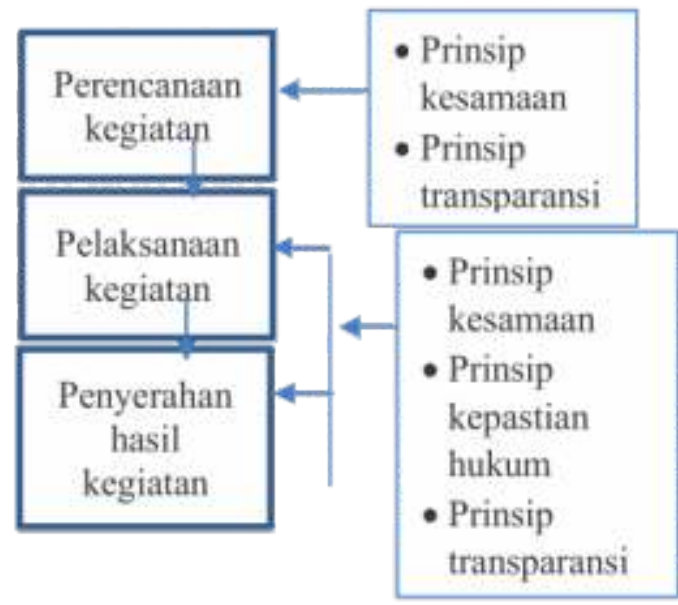

(Sumber: Konsep Pemikiran, 2019)

Gambar 2

Penerarapan Prinsip Pemerintahan Yang Baik Di Dalam PTSL.

Berdasarkan laporan kegiatan PTSL tahun 2019, secara umum Kantor Pertanahan Kabupaten Kepahiang telah melaksanakan kegiatan PTSL sesuai dengan ketentuan. Target kegiatan sebanyak 1.360 bidang tanah telah diselesaikan dengan tingkat pencapaian sebesar $100 \%$. Pelaksanaan kegiatan tersebut lingga penyerahan sertipikat berlangsung sejak bulan Maret hingga Agustus 2019. Penyelesaian kegiatan PTSL sebelum berakhirrya tahun anggaran menunjukkan adanya tata kelola pekerjaan yang baik. Selain itu tidak adanya masalah baik secara adminisirasi maupun hukum menunjukkan adanya sistem pengawasan dan kendali mutu yang berjalan dengan baik.

Petugas PTSL yang telah bekerja dengan baik menurut pengamatan dan wawancara menunjukkan kepuasan dìrì karena target telah tercapai. Pada dasarnya petugas teknis dan administrasi tidak keberatan bekerja secara profesional dan bersikap integritas dan akuntabel dengan alasan lebih terjamin tidak adanya gugatan atau konsekuensi hukum yang merugikan. Selama bekerja di lapangan petugas juga mendapatkan sambutan baik dari masyarakat termasuk kerjasama sehingga pekerjaan berjalan lancar dan selesai lebih cepat dari target wakiu.

Penyelenggaraan kegiatan PTSL menghasilkan penerbitan sertipikat secara massal yang diakumulasikan akan menjadi akses permodalan bagi masyarakat. Selanjutnya akses permodalan tersebut dapat digunakan untuk program pemberdayaan masyarakat.

\section{Fakter-Faktor Keberhasilan Untuk Terwujudnya Tata Kelola Pemerintahan Yang Baik}

Penerapan tata kelola pemeritahan yang baik berlaku untuk semua kegiatan pertanahan. Setiap kegiatan Pendaftaran Tanah Sistematis Lengkap (PTSL) mempunyai pengaruh terhadap kegiatan lainnya dan secara keseluruhan harus dipenuhi untuk pencapaian hasil akhir yaitu penerbitan sertipikat. Sebaliknya apabila tidak dilakukan secara benar atau ada kegiatan yang terlewatkan akan berakibat cacat administrasi dan bahkan dapat berkonsekuensi hokum.

Tabel di bawah ini menunjukkan keterkaitan pekerjaan PTSL dengan tata kelola pemerintahan sebagai berikut:

Tabel 2

Keterkaitan Pekerjaan PTSL Dengan Konsekuensi Penerapan Dan Pengabaian Tata Kelola Pemerintahan

\begin{tabular}{|l|l|l|}
\hline Kegiatan & $\begin{array}{l}\text { Dampak } \\
\text { Penerapan }\end{array}$ & $\begin{array}{l}\text { Dampak } \\
\text { Pengabaian }\end{array}$ \\
\hline $\begin{array}{l}\text { Perencanaan } \\
\text { kegiatan }\end{array}$ & $\begin{array}{l}\text { Kepastian } \\
\text { kegiatan }\end{array}$ & $\begin{array}{l}\text { Kegagalan } \\
\text { kegiatan }\end{array}$ \\
\hline Penyuluhan & $\begin{array}{l}\text { Kejelasan } \\
\text { informasi }\end{array}$ & $\begin{array}{l}\text { Kesimpang- } \\
\text { siuran } \\
\text { informasi }\end{array}$ \\
\hline
\end{tabular}




\begin{tabular}{|l|l|l|}
\hline $\begin{array}{l}\text { Pengumpulan } \\
\text { data }\end{array}$ & $\begin{array}{l}\text { Kelengkapan } \\
\text { data }\end{array}$ & $\begin{array}{l}\text { Kekurangan } \\
\text { data }\end{array}$ \\
\hline Penelitian data & $\begin{array}{l}\text { Keakuratan } \\
\text { data }\end{array}$ & $\begin{array}{l}\text { Kelemahan } \\
\text { data }\end{array}$ \\
\hline $\begin{array}{l}\text { Pengumuman } \\
\text { data }\end{array}$ & $\begin{array}{l}\text { Pengakuan } \\
\text { kebenaran } \\
\text { data }\end{array}$ & $\begin{array}{l}\text { Potensi klaim } \\
\text { sengketa tanah }\end{array}$ \\
\hline Penetapan hak & $\begin{array}{l}\text { Kepastian hak } \\
\text { atas tanah }\end{array}$ & $\begin{array}{l}\text { Potensi cacat } \\
\text { administrasi } \\
\text { dan atau cacat } \\
\text { hukum }\end{array}$ \\
\hline $\begin{array}{l}\text { Pembukuan } \\
\text { hak }\end{array}$ & $\begin{array}{l}\text { Kepastian } \\
\text { status tanah }\end{array}$ & $\begin{array}{l}\text { Ketidakjelasan } \\
\text { status tanah }\end{array}$ \\
\hline $\begin{array}{l}\text { Penerbitan } \\
\text { sertipikat }\end{array}$ & $\begin{array}{l}\text { Pengakuan } \\
\text { hak atas tanah }\end{array}$ & $\begin{array}{l}\text { Potensi } \\
\text { gugatan hat hak } \\
\text { atas fanah }\end{array}$ \\
\hline
\end{tabular}

(Sumber: hasil olahan 2019)

Berdasarkan Tabel di atas, tata kelola pemerintahan akan berpengaruh terhadap hasil antara dan hasil akhir kegiatan PTSL. Apabila tafa kelola pemerintahan dijalankan maka dampak yang ditimbulkan adalah berjalannya kegiatan sesuai dengan target. Sebaliknya apabila tata kelola pemerintahan diabaikan maka akan memberikan dampak yang tidak diharapkan bahkan hingga menghasilkan kegagalan.

Faktor-faktor yang dapat memberikan keberhasilan mencapai tata kelola pemerintahan yang baik dapat dilihat pada tabel di bawah ini.

Tabel 3

Faktor-Faktor Keberhasilan Tata Kelela Pemerintahan di Dalam PTSL

\begin{tabular}{|l|l|}
\hline $\begin{array}{l}\text { Faktor } \\
\text { Keberhasilan }\end{array}$ & Situasi Yang Dihasilkan \\
\hline Kepentimpinan & - Arah pekerjaan yang \\
& jelas sesuai kebijakan \\
& $\begin{array}{l}\text { Target pekerjaan sesuai } \\
\text { rencana }\end{array}$ \\
& - Penanaman nilai-milai \\
& moral dan profesional \\
& dalam bekerja \\
\hline
\end{tabular}

\begin{tabular}{|c|c|}
\hline Budaya Kerja & $\begin{array}{l}\text { - Sikap moral dan } \\
\text { profesional petugas } \\
\text { terbentuk } \\
\text { - Sikap saling } \\
\text { mengingatkan dan } \\
\text { mencegah korupsi }\end{array}$ \\
\hline $\begin{array}{l}\text { Kejelasan } \\
\text { Skandar } \\
\text { Pekerjaan }\end{array}$ & $\begin{array}{l}\text { - Memberikan standar } \\
\text { prosedur yang harus } \\
\text { dilakukan } \\
\text { - Memberikan standar } \\
\text { kualitas yang harus } \\
\text { dipenuhi } \\
\text { - Memberikan standar } \\
\text { kinerja yang harus } \\
\text { dicapai }\end{array}$ \\
\hline $\begin{array}{l}\text { Peraturan dan } \\
\text { Petunjuk Teknis } \\
\text { yang tersedia }\end{array}$ & $\begin{array}{l}\text { - Memberikan informasi } \\
\text { tentang aturan yang } \\
\text { harus diikuti } \\
\text { - Memberikan batasan } \\
\text { dalam bentuk } \\
\text { persyaratan yang harus } \\
\text { dikenakan untuk suatu } \\
\text { produk hukum }\end{array}$ \\
\hline
\end{tabular}

(Sumber: hasil olahan 2019)

Faktor-faktor keberhasilam pada Tabel di atas menunjukkan bahwa dalam penyelenggaraan kegiatan PTSL memerlukan pengerahan segala sumber daya yang ada dalam suatu organisasi. Situasi yang dihasilkan oleh masing-masing faktor keberhasilan tersebut di atas merupakan bagian-bagian pencapaian tata kelola pemerintahan yang baik. Apabila seluruh situasi yang dihasilkan oleh berbagai faktor tersebut terwujud, maka penyelenggaraan PTSL. dapat memenuhi kriteria tercapainya tata kelola pemerintahan yang baik.

Faktor-faktor keberhasilan tata kelola pemerintahan yang baik dapat dibubungkan dengan sistem kebjjakan publik berdasarkan Gambar di bawah ini 


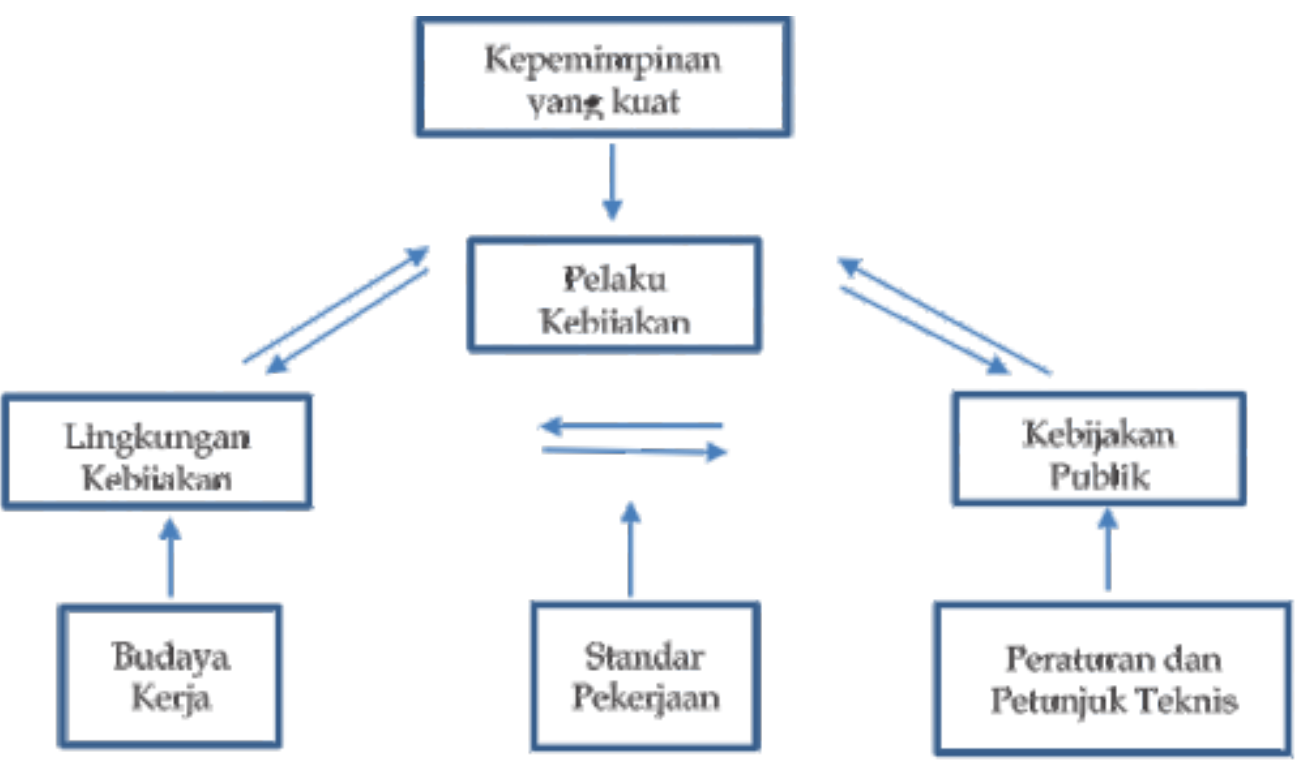

Sumber: Konsep Pemikinan, 2019)

\section{Gambar 3 \\ Faktor-Faktor Keberhasilan Terwujudnya Sistem Kebijakan Publik}

Gambar di atas menunjukkan faktorfaktor keberhasilan terwujudnya tata kelola pemerintahan yang baik dapat diterapkan dalam sistem kebijakan publik. Kepemimpinan dari suatu satuan kerja yang menyelenggarakan PTSL dapat membentuk perilaku pelaku kebijakan melalui pengaruh, visi dan pemberian motivasi. Lingkungan kebijakan yang baik dapat diwujudkan melahui budaya kerja dari satuan kerja serta terdapatnya standar pekerjaan. Terakhir adalah kebijakan publik yang dihasilkan harus bersandarkan pada peraturan dan petunjuk teknis terkait penyelenggaraan PTSL.

\section{PENUTUP}

Pemaparan tahapan kegiatan Pendaftaran Tanah Sistematis Lengkap (PTSL) memberikan tempat bagi pelaksanaan prinsip-prinsip pemerintahan yang baik. Penerapan prinsipprinsip tersebut menjadi suatu yang harus dipenuhi mengingat tekad Kementerian Agraria dan Tata Ruang/ Badan Pertanahan Nasional adalah mewujudkan tanah bagi sebesar-besar kemakmuran rakyat. Dengan demikian rakyat akan semakin mudah untuk memperoleh hak atas tanah dan lebih jauh lagi menjadikan sertipikat hak atas tanah sebagai akses permodalam untuk kegiatan usaha.
Faktor-faktor keberhasilan untuk tercapainya tata kelola pemerintahan yang baik di dalam penyelenggaraan PTSL meliputi kepemimpinan, budaya kerja, standar pekerjaan serta peraturan dan petmijuk teknis. Keempat faktor tersebut dapat dijadikan faktor pendorong berialannya sistem kebijakan publik.

Sebagai tindak lanjut dari tulisan ini adalah perlunya penelitian mengenai seberapa jauh dukungan dari Pemerintah Daerah untuk pemberdayaan masyarakat pasca diterimanya sertipikat hak atas tanah.

\section{REFERENSI}

Dwiyanto, A. 2014. Mengapa Pelayanan Publik. Dalam Dwiyanto, A (ed), Mewujindkan Good Governance Melalui Pelayanan Publik. Gadjah Mada University Press: Yogyakarta. Hal. 17-42

Dunn, W.N. 2000. Pengantar Analisis Kebijakan Publik. Gadjah Mada University Press: Yogyakarta

Heriyanto, A. 2015. Penerapan Prinsip-Prinsip Good Governance Dalam Tata Kelola Pemerintahan Desa Triharjo Kecamatan Sleman Kabupaten Sleman. Repository, Universitas PGRI Yogyakarta. http://repository.upy.ac.id/177/ . Diakses tanggal 22 Okiober 2019 
Komite Nasional Kebijakan Governance, 2008. Pedoman Umum Good Public Governance Indonesia.

Kumorotomo, W. 2015. Etika Administrasi Negara. Penerbit Rajawali Pers; Jakarta

Kumiawan, W.A., Setiowati, S. dan Supriyanti, T. 2018. Ekspektasi Pendafiaran Tanah Sistematis Lengkap Terhadap Faktor Sosial dan Ekonomi Masyarakat. Jurnal Tunas Agraria, Vol. 1 (1), hal. 1-19

Nugroho, R. 2009. Public Palley; Dinamika Kebijakan-Analisis Kebijakan-Manajennen Kebijakan. PT. Elex Media Komputindo: Yogyakarta

Pratikno. 2005. Good Governance dan Governability. Jurnal Ilmu Sosial dan Ilmu Politik. Vol. 8 (3), hal. 231-248

Prianto, A.L. 2011. Good Governance dan Formasi Kebliakan Publik Nea Liberal. Otoritas Jurnal Jlmu Pemerintahan, Vol. 1 (1), hal. $1-10$

Putra, H.S. 2017. Tata Kelola Pemerintahan Desa Dalan Mewujudkan Good Governamce Di Desa Kalibelo Kabupaten Kediri. Jumal Politik Muda, Vol. 4 (2), hal. 110-119

Ridwan, R. 2013. Hukum Administrasi Negara. Rajawali Pers: Jakarta.

Subarsono, AG. 2014. Pelayanan Publik Yang Eflsien, Responsif dan Non Partisan. Dalam Dwiyanto, A (ed), Mewujudkan Good Governance Melatui Pelayanan Publik. Gadjah Mada University Press: Yogyakarta. Hal. 135-172

UNESCAP. Tampa tahun. What is Good Governance.

https:/www.unescap.org/sites/default/files/go od-governancepdf . Diakses tanggal 22 Oktober 2019

Widodo, I. 2018. Analisis Kebijakan Publik. Penerbit Media Nusa Creative: Malang 
